\title{
The Discourse Analysis of Social Factors Influencing Interest Contention in Business Dispute Settlement: A Perspective of Discourse Information Theory
}

\author{
Tingting Guo ${ }^{1,2}$, Zhenxia Zhao ${ }^{3} \&$ Xinghua $\mathrm{Han}^{4}$ \\ ${ }^{1}$ School of Foreign Languages, Zhongyuan University of Technology, Zhengzhou, Henan, China \\ ${ }^{2}$ Postdoctoral Research Station of Chinese Language and Literature, School of Liberal Arts, Zhengzhou \\ University, Zhengzhou, Henan, China \\ ${ }^{3}$ School of International Business, Southwestern University of Finance and Economics, Chengdu, Sichuan, \\ China \\ ${ }^{4}$ Zhengzhou Institute of Technology, Zhengzhou, Henan, China \\ Correspondence: Tingting Guo, Zhongyuan University of Technology, No. 41, Middle Zhongyuan Road, \\ Zhengzhou 450007, China. Tel: 86-136-7337-0856. E-mail: 532955649@qq.com
}

Received: January 30, 2019 Accepted: February 21, 2019 Online Published: February 28, 2019

doi:10.5539/ass.v15n3p46

URL: https://doi.org/10.5539/ass.v15n3p46

\begin{abstract}
Interest contention which reflects the nature of business dispute settlement is one of the vital issues to explore in the studies of business dispute and it structures the whole process of business dispute settlement from mediation, negotiation to arbitration and litigation. Under the influence of various factors, litigants with differing interest orientations and interest demands could make good use of a number of information resources for the purpose of communicating, defending and fighting for the interests of their own. Contexts are a socially based mental model dynamically constructed by participants about "the for-them-relevant properties" of communicative situation (van Dijk, 2008). The social factors in the context influences the distribution of discourse information resources in the interest contention in business dispute settlement. In view of this, the present study focuses on the discourse analysis of social factors influencing the interest contention in business dispute settlement at the stage of litigation from the perspective of Discourse Information Theory (DIT) (Du, 2007, 2013, 2015). It can be found that any conflicting party's lawyer could take advantage of both different social identities and social relationships to attack the counterparty's loopholes or shortcomings and gain more interests for his own party in the interest contention in business dispute settlement.
\end{abstract}

Keywords: business dispute settlement, Discourse Information Theory (DIT), interest contention, social factor

\section{Introduction}

In the process of business dispute settlement, interest contention constitutes the kernel of business dispute settlement. Many scholars (e.g. Fan, 2007; Vestergaard et al., 2011) have conducted relevant studies concerning the influencing factors of dispute or conflict settlement and found that social, psychological and cultural factors could affect the settlement of conflict or dispute. The influencing factors include social, psychological and cultural factors and they have different manifestations under different circumstances. However, the present study only focuses on how social factors influence interest contention in business dispute settlement from the perspective of discourse information theory (DIT).

\section{Literature Review}

\subsection{Relevant Studies on Social Factors Influencing Dispute Settlement}

Fan (2007) in her "Social System of Dispute Settlement" proposes the factors influencing dispute settlement. Among the factors, some are related to the social factors, for example, relationship between the disputing parties, spatial and temporal factors, etc. Many scholars argue that the social factors affect the speaker's discourse (e.g. van Dijk, 2008). van Dijk (2008) proposes that the social factors such as personal identity, communicative identity as a speaker, political identity as PM, etc. affect the speaker's discourse when van Dijk analyzes the example of Tony Blair's address. And Vestergaard et al. (2011) propose a practice-oriented model of five 
dimensions of conflict, namely, structural, instrumental, interest, value or personal dimension. And among the five dimensions of conflict, the structural dimension is related to the social perspective. When people are in conflict, they usually have a need that has not been met. This need is often linked to one or more of the five different dimensions. Besides, texts are social spaces in which two fundamental social processes simultaneously occur: cognition and representation of the world, and social interaction (Faiclough, 1995). Following Halliday's (1978) systemic linguistics, Faiclough (1995) proposes that texts in their interpersonal functioning constitute social subjects (or in different terminologies, identities, forms of self) and social relations between (categories of) subjects. Although there are extensive studies of social factors influencing dispute settlement and its discourse, how social factors influence business dispute settlement still remains at a tentative level.

\subsection{Previous Studies on Discourse Information Theory (DIT)}

$\mathrm{Du}$ (2007) puts forward the linguistic model of information structure of legal discourse, and this is the core model of Discourse Information Theory. Based on this core model, the Discourse Information Theory has been developed systematically by researchers (e.g. Du, 2007, 2009, 2013, 2015; Zhao, 2011; Chen, 2011; Pan \& Du, 2011; Huang, 2012; Ge, 2014; Xu, 2013; Zhang, 2016; Guan, 2015; Sun, 2016; Yue, 2016; Guo, 2017) for more than ten years.

In contrast to the common practice to consider information as a sentence-level notion, $\mathrm{Du}$ (2015) defines information as propositions which are the minimal communication units with a relatively independent and complete structure. $\mathrm{Du}$ (2007) puts forward the linguistic model of information structure of legal discourse, and this is the core model of Discourse Information Theory. A series of theoretical and applied studies of DIT are conducted based on this core model.

On the one hand, a number of studies have made further contributions to the theoretical development of DIT. Models and frameworks have been put forward to help solve different problems in the fields of linguistics, forensic linguistics and business English studies in particular (e.g. Zhao, 2011; Chen, 2011; Du, 2013; Xu, 2013; Ge, 2014; Zhang, 2016; Guan, 2015; Sun, 2016; Yue, 2016; Guo, 2017).

On the other hand, through years of research and development, the Discourse Information Theory (DIT) and Discourse Information Analysis (DIA) have been applied to legal discourse analysis (Du, 2015; Ge, 2014; Pan \& $\mathrm{Du}, 2011$; Xu, 2013; Zhang, 2016), legal translation and interpreting (Zhao, 2011), legal English teaching (Chen, 2017), authorship attribution (Zhang, 2016), forensic speaker recognition (Guan, 2015), conflict management in business meetings (Yue, 2016), interest contention in business dispute settlement (Guo, 2017), and automatic information processing (Du, 2015; Sun, 2016).

\section{Theoretical Framework and Methodology}

\subsection{Discourse Information Theory (DIT)}

The tree information structure of legal discourse ( $\mathrm{Du}, 2007,2015)$ is regarded as the basic and core framework of Discourse Information Theory. A discourse is a hierarchical structure consisting of proposition-based information units that are the minimal, integral and meaningful units that have relatively independent complete meaning and structure. In the development of a discourse, the proposition-based information units are woven into an information network and they are related to each other in one way or another. This view of discourse is regarded as the core model of Discourse Information Theory, namely the tree information structure of Discourse Information Theory ( $\mathrm{Du}, 2013,2015)$.

\subsection{Research Methodology}

The present study mainly adopts the qualitative research method with the assistance of the corpus CLIPS. Specifically, the methods of discourse analysis, Discourse Information Analysis (DIA) and corpus study are employed as the major methodologies for data analysis in the present research.

\subsubsection{Data Collection}

In order to ensure the reliability and validity of the study, all the data are extracted from CLIPS (the Corpus for the Legal Information Processing System) which consists of transcripts of Chinese and American civil court trials. The data collected are mainly recordings of observed court proceedings, which were collected with professional digital voice recorders with the permission of the court and the consent of both parties (Ge, 2014). All of the discourses in CLIPS have been transcribed and tagged according to transcription and tagging conventions based on Discourse Information Theory (DIT).

\subsubsection{Data Analysis}

The data analysis can be illustrated by the following sample: 
Sample:

01[审判长]: $<1,2,2,14, \mathrm{WT}>$ 现在核对证据提交情

况。<2,14,3,26,WF1 $>$ 原告庭前向本院提交了几份 证据?

02[原告代理律师]: $<2,14,3,26, \mathrm{WF} 2>$ 原告庭前向 法院提交了 9 份证据。

03 [审判长]: $<2,14,3,27, \mathrm{WF} 3>$ 被告收到了吗?

04[被告代理律师]: <2,14,3,27,WF4>收到。
01[J]: $<1,2,2,14$,WT $>$ Now check the evidence submitted. $<2,14,3,26$, WF1 $>$ How many copies of evidence has the plaintiff submitted to the court before the hearing?

$02[\mathrm{PA}]:<2,14,3,26, \mathrm{WF} 2>$ The plaintiff has submitted 9 copies of evidence to the court before the hearing.

$03[\mathrm{~J}]:<2,14,3,27, \mathrm{WF} 3>$ Has the defendant received them?

$04[\mathrm{DA}]:<2,14,3,27, \mathrm{WF} 4>$ The defendant has received them.

As is illustrated in the above sample, the numbers before the square brackets refer to the turns of speech. The symbols in the angle brackets are the description of the characteristics of information units. Numbers " $1,2,2,14$ " at the very beginning of the transcription represent the level of the information unit in the whole discourse, that is, the 14th unit of the 2 nd level ("2,14"), with its super-ordinate unit being the 2 nd unit of the 1st level (" 1,2 ").

And the signs of information level can help to locate specific information units in the whole discourse. "WT" and "WF" refer to the types of information knots, namely, "What Thing" and "What Fact" respectively. "J" refers to the chief judge, "PA" refers to the plaintiff's attorney and "DA" refers to the defendant's attorney.

\subsubsection{Research Questions}

In order to achieve the research objective, two research questions are formulated as follows:

1). What social factors influence the interest contention in the courtroom discourse concerning business dispute settlement?

2). How does the specific social factor influence the interest contention in the courtroom discourse concerning business dispute settlement?

\section{Discourse Analysis of Social Factors Influencing Interest Contention in Business Dispute Settlement}

\subsection{Discourse Analysis of the Effect of Social Identities}

The social identities of participants play an important role in their interest contention. Different social identities can help the participants, especially the lawyers to attain their argumentative goals in the court. In this section, the analysis is specifically done from the perspective of social identities.

\subsubsection{The Use of Positive Social Identity}

In the interest contention in business dispute settlement, social identity may function as one of the key factors that influence interest contention in business dispute settlement. The disputing parties in business dispute settlement can utilize social identities for interest contention.

Example 1:

01[被代二]: ......<4,73,5,58,WF1>下一幅 ppt 当中显示, 从 13 年到 14 年 3 月一年内, 原告就被 5 个地方一北京、南京、南昌、

上海、杭州五地网友相聚起诉原告窃取隐

私。<4,73,5,59,WF2 $>$ 再下一张我们显示的

是最近中消协网站上报告显示: 原告市场

占有率排第一的 $\times \times \times$ 浏览器存在窃取用

户隐私, 监控用户上网等方面问题非常突

出, 安全软件不安全导致用户满意度倒数

第二。......
01[DA2]: ... $<4,73,5,58$, WF1 $>$ Next piece of ppt shows that the plaintiff has been sued for stealing Internet users' privacy by the Internet users coming from five places, namely, Beijing, Nanjing, Nanchang, Shanghai, and Hangzhou during the year from 2013 to the March of 2014. <4,73,5,59, WF2 $>$ And then what the next piece of ppt shows us is that the plaintiff's $x \times \times$ browser which ranks first in the market exists the prominent problems like stealing their users' privacy, monitoring their users' actions on the Internet and so on according to the report on the website of China Consumers Association recently. And this insecurity of secure software has resulted in the users' satisfaction at the penultimate place ...

This example is the defendant's statement which is a part of the proof presentation concerning the evidence of infringement in court investigation.

In Example 1, the social identity of the plaintiff which is proposed in WF2 has been highlighted to help the defendant to blame the plaintiff's irresponsible behaviors and increase the persuasive power of the defendant's claims. For the plaintiff, the positive social identity indicates more responsibilities. However, this positive social identity of plaintiff is related to the fact that the plaintiff has stolen their users' privacy, which helps the defendant to blame the plaintiff's irresponsible activities.

Besides, the relatively authoritative third party's release of this fact from China Consumers Association can help the defendant to increase persuasive power and objectivity of the fact. 
In addition, the disputing interest focus is on the issue that whether the plaintiff has stolen their Internet users' information and privacy on the Internet or not. Example 1 is one of the proof presentations to testify that the defendant's behavior of converging online news headlines on their website is based on facts rather than the defamation of the plaintiff's commercial reputation.

The defendant's providing of proofs is mainly supported by the plaintiff's negative actions based on his positive social identity establishment. WF2 states that the market position of the plaintiff's browsers with “原告市场占 有率排第一的 $\times \times \times$ 汶览器” (the plaintiff's $\times \times x$ browser which ranks first in the market) according to the online report of China Consumers Association and this helps to establish the plaintiff's positive social identify at first. However, WF2 followingly points out that some problems of the plaintiff are quite serious, such as stealing the users' privacy and monitoring users' online behaviors. And this negative action of the plaintiff is in fact what the defendant wants to emphasize.

Moreover, the example is initiated by the defendant's presentation of Internet users' charge for the plaintiff's stealing of users' privacy on the Internet with WF1 unit in order to emphasize the objectivity and seriousness of the plaintiff's theft during the last year before the lawsuit.

Following that, another information unit of WF2 is provided to prove the fact that the plaintiff has met several problems on stealing the Internet users' privacy and monitoring the users' actions on the Internet based on an authoritative website of China Consumers Association, in which an explicit positive social identity is utilized to show the plaintiff's superior place in the market initially and then its corresponding negative or irresponsible behaviors are revealed on this basis to increase the objectivity of the plaintiff's insecure or irresponsible behaviors and the acceptability of their claims.

Besides, this can lead to the blame of the plaintiff's irresponsible behaviors and reduce the trust in this acknowledged safe software used by the majority of the Internet users.

We can see that the defendant has presented the proof concerning the plaintiff's negative actions which are based on the plaintiff's positive social identity establishment by means of authoritative quotation. The contrast between the plaintiff's positive social identity and his irresponsible actions can help to increase the blame to him and the utilization of WF information units from authoritative quotation help to increase the objectivity of the plaintiff's irresponsible behaviors and the acceptability of the claims to persuade the chief judge that his behavior of converging online news headlines is based on objective facts rather than defaming of the plaintiff. Since this proof is presented and challenged by the disputing parties for several rounds of proof presentation and proof challenge, one of the major interest foci which is mainly based on this piece of evidence is to be summarized and presented by the chief judge later at the stage of defining conflicts and interests. Thus, this example shows the key role of social identity in interest contention in business dispute settlement at the stage of defining the interest and conflict.

The following Example 2 is another example by means of taking advantage of the positive social identity establishment to testify the truth of the 3rd piece of evidence provided by the defendant. In this example, the defendant lawyer presents the proof to justify that loopholes indeed exist in the plaintiff's browser for mobile phones at the stage of defining interests and conflict.

Example 2:

$01[$ 被代二]: ..... $<3,58,4,92, \mathrm{WF} 1>$ 证据 3 是 对 $\times \times$ 漏洞平台所公开部分漏洞平台介绍厂 商列表。 $<3,58,4,93, \mathrm{WF} 2>$ 我们可以证明 $\times \times$ 漏洞平台是自开站以来已经公布了 5 万多个 漏洞, 为网络的安全作出了巨大贡献。 $<3,58,4,94, \mathrm{WF} 3>$ 甚至与国家信息安全漏洞 共享平台, 以及国家信息应急中心进行了权 威合作, $<3,58,4,95$, WI $>$ 所以 $\times \times$ 漏洞平台是 行业内具有权威性的漏洞发布。 $<3,58,4,96$, WI $>$ 就我们刚才的技术说明以及 $\times \times$ 漏洞平台的一个权威性证明, 我们可以 证明 $\times \times$ 漏洞平台关于原告 $\times \times \times$ 手机浏览 器缺陷导致用户敏感数据泄露这一漏洞是真 实、客观存在的, 也获得了原告自己的确认。 陈述完毕。
01 [DA2]: ...<3,58,4,92, WF1 $>$ Evidence 3 is a list of relevant factories and vendors released to the public by $\times \times$ loophole platform. $<3,58,4,93$, WF2 $>$ We can prove that $\times \times$ loophole platform has already announced more than 50,000 loopholes and made a great contribution to network security since the opening of the loophole platform. $<3,58,4,94$, WF3 $>$ It has even conducted the authoritative cooperation with National Information Security Loophole Sharing Platform and National Emergency Information Center. $<3,58,4,95$, WI $>$ Thus, $\times \times$ loophole platform is an authoritative loophole releasing platform within this industry. $<3,58,4,96$, WI $>$ Based on the technical descriptions made just now and the proof of the authoritativeness of $\times \times$ loophole platform, we can prove the truth and objectivity of the loophole concerning the defects of $x \times \times$ mobile phone browser resulting in the leakage of his user' sensitive data released by $\times \times$ loophole platform and this has received the plaintiff's confirmation as well. Statement is over.

At the stage of defining interests and conflict, both of the disputing parties try their best to justify the objectivity 
and truth of the proofs they presented. Each party has the right to question the presented proofs to protect and strive for his own interest. If they are successful in doing so, the identification of mutual interest foci summarized by the court may help them to stay in an advantageous position for contending for more interest at the next stages of examining and testing possible solutions for dispute settlement.

However, herein the positive or contributive behaviors based on the positive social identity establishment with the expression like “ $\times x$ 漏洞平台是行业内具有权威性的漏洞发布” $(x \times$ loophole platform is an authoritative platform which releases loopholes within this industry) are listed with the information unit of WF to increase its objectivity and strengthened by the previous 3 information units of WF1, WF2, and WF3 to enhance the credibility of its authoritativeness and the acceptability by the court for defining the interest foci later.

\subsubsection{The Use of Negative Social Identity}

In addition to the usage of positive social identity, the social identity establishment from the negative perspective can also be utilized by both disputing parties to contend for more interests for themselves in business dispute settlement.

Example 3:

$01[$ 原代一 $]: \ldots . . . \times \mathrm{WF} 1>\times \times \times$ 网站在它这个历史上有过 发文去诋毁 $\times \times$ 手机，诋毁 $\times \times$ (某手机品牌) 等等这 样的事实。 $<\mathrm{WF} 2>$ 也就是说, $x \times$ 网站本身是一个提 供驱动下载的网站, 但是它发了一些其他公司的负 面的抹黑文章, 比如说我们的这个 ppt 当中展示的这 个关于 $\times \times$ (某手机品牌) 的和其他的一些软件的一 些抹黑文章。 $<\mathrm{WI}>$ 这些证据能够证明 $\times \times$ 网站不是一 个, 不是一个权威的网站, 也不是一个公正的新闻 网站。

02[审判长]: <WT>被告发表质证意见，就针对原告 的证据 4 和证据 8 一并陈述一下吧。
01[PA1]: ... $<\mathrm{WF1} 1>\times \times$ website in its history has issued articles to discredit $x \times$ phone, $x \times$ mobile phone, and some other similar facts. $<$ WF $2>$ That is to say, $\times \times$ website itself is a website to provide driver download service, but it has issued a number of articles to discredit other companies, for example, we have shown those articles to discredit $x \times$ mobile phone and some other software in our ppt. $<$ WI $>$ Those evidence can prove that $x \times$ website is neither an authoritative website, nor a fair news site.

$02[\mathrm{~J}]: \quad<\mathrm{WT}>$ The defendant issue statements on the proof cross-examination and issue the statement on the evidence 4 and 8 presented by the plaintiff together.

As is shown in Example 3, the aim of negative social identity establishment of $x \times$ website by the plaintiff is to blame the counterparty for the incredibility of the defendant's proof presentation.

In the previous round of proof presentation, the defendant has presented evidence 5 to prove the authority and objectivity of $\times \times$ website.

At this stage of defining interest and conflict, whether the articles issued by $x \times$ website are authoritative and objective plays an important role in interest contention for both disputing parties in that if the articles issued by $x \times$ website are accepted as objective, truthful and authoritative, the chief judge's judgment is probably in favor of the defendant. Thus, the negative social identity establishment of $x \times$ website by the plaintiff is quite important for their interest contention.

It can be found that WI information unit realizes the establishment of negative social identity of $\times \times$ website with WI unit of “这些证据能够证明 $x \times$ 网站不是一个, 不是一个权威的网站, 也不是一个公正的新闻网站” (those evidence can prove that $\times \times$ website is neither an authoritative website, nor a fair news site). And this WI information unit is drawn based on the previous two WF information units. Here, the two WF information units are used to present the facts and provide objective basis for the following inference.

Example 4:

$01[$ 原代一]: $\ldots . . .<\mathrm{WA}>$ 那么对于证据 5 呢, 我们对 这个形式上的真实性呢, 我们是认可的。但是, 我们 对内容真实性是有异议的, $<\mathrm{WY}>$ 因为 $\times \times$ 网站呀, 是一个提供驱动程序的网站, 并不是一个新闻媒体网 站, <WF>那么它也存在一些其他的抹黑其他企业的 一些行为, 我们也进行了举证, $<\mathrm{WI}>$ 因此这个证据 不能够证明 $\times \times$ 网站是一个新闻媒体单位。 $<\mathrm{WT}>$ 这 是对证据 4 和证据 5 的质证意见。
01[PA]: $\ldots<\mathrm{WA}>$ As for evidence 5 , we recognize its authenticity in the form. However, we are against the authenticity of its content, $<\mathrm{WY}>$ because $\times \times$ website is a website that provides driver programmes rather than a news media site, $<W F>$ but $x \times$ website has also discredited other companies, and we've also presented the evidence, $<$ WI $>$ so this evidence cannot prove that $x \times$ website is a news media. $<\mathrm{WT}>$ This is our views on challenging evidence 4 and 5 .

In Example 4, this example is concerned with the plaintiff lawyer's views on challenging evidence 5. And evidence 5 is the notarial certificate which testifies that $\times \times$ website is an authoritative news media according to the evaluation of $x \times$ website of $x \times$ encyclopedia.

In this example, WA proposes that the plaintiff lawyer only admits the authenticity of evidence 5 in form and doesn't recognize the truth of the content of evidence 5. And the content of evidence 5 is not in favor of the 
plaintiff's interest contention. In order to support the views proposed in WA information unit, the following WY information unit demonstrates that $x \times$ website is a website which provides the service of driver programme rather than a news media. Moreover, WF unit provides the fact that the behaviors of $x \times$ website to discredit other corporations indeed exists. This negative social identity establishment of $x \times$ website can help reduce the credibility of evidence 5 and enhance the acceptability of the plaintiff lawyer's views on challenging evidence 5 . Then, the WI unit infers that evidence 5 cannot prove that $x \times$ website is not a news media like “因此这个证据 不能够证明 $x \times$ 网站是一个新闻媒体单位” (so this evidence cannot prove that $\times x$ website is a news media). This is also the negation of the social identity of a news media of $\times \times$ website.

Apart from the explicit usage of social identities, some other relative implicit linguistic or paralinguistic performance is also influenced by their social identities respectively in the contention for interest.

For example, in the following Example 5, the chief judge uses the interruption to control the court trial proceeding. Moreover, the plaintiff lawyer agrees with the judge's control accompanied with continuous nodding to show agreement and obedience. In the court, from the perspective of social identities, the judge is not only the symbol of justice and fairness, but also the party with relative more power than other participants involved. Compared with the chief judge, the lawyers have relatively less power. Thus, the implicit linguistic of chief judge's interruption and the paralinguistic performance of plaintiff lawyer's continuous nodding are influenced by their social identities respectively in interest contention in business dispute settlement.

\subsubsection{The Use of Social Identity with Power}

In court trials, the chief judge is often the party with more power compared with other participants involved and many studies (e.g. Wodak, 1985; Conley \& O'Barr, 1998; Cotterill, 2003; Gibbons, 2003) have investigated the power in courtroom discourse from different perspectives.

In order to maintain the regular proceeding of the court hearing, the chief judge usually uses the power to control the court trial proceeding. For example, interruption is sometimes used by the chief judge in the court to re-allocate speech turns to regulate the normal proceeding of court trials, when he finds a topic is over elaborated by one participant or another party's interest needs to be emphasized instead.

\section{Example 5:}

01 [审判长]: $<3,45,4,45, \mathrm{WA} 1>$ (打断) 原告, 原告, 法庭提醒你注意一下，如果涉及到法律问题，可 以留待法庭辩论阶段再进行。现在请就证据问题 陈述一下你方意见即可。好吗?

$02[$ 原代一]: $<3,45,4,45, \mathrm{WA} 2>$ 哦 (点头) 好! 哦, 好的!好的!好的!好的!.......
$01[\mathrm{~J}]:<3,45,4,45$, WA1 $>$ (interruption) The plaintiff, the plaintiff, the court remind you that if it is related to legal issues and it can be left to the stage of court debate to be discussed. Please state your party's views on the issue of evidence. OK?

02[PA1]: $<3,45,4,45$, WA2 $>$ Oh (nodding) OK! Oh, OK! OK! OK! $\mathrm{OK} ! \ldots$

In Example 5, the interaction between the plaintiff and the chief judge occurs at the stage of defining interest and conflict, both conflicting disputants want to try their best to persuade the chief judge to adopt or agree on their views and their evidence presentation. Prior to this interaction, the plaintiff lawyer has presented the evidence concerning infringement behavior involved in the case. And the plaintiff lawyer has also begun to argue and overelaborate some key information in the presented evidence. However, the plaintiff lawyer's overelaboration and argument on some key information is related to the legal issues which should be presented and argued later at the stage of court debate. Thus, the chief judge in this example interrupts the plaintiff lawyer.

In this way, the points which are in favor of their interest attainment are emphasized by the plaintiff's or the defendant's lawyer(s) for many times. In the preceding evidence presentation of this example, the plaintiff lawyer has emphasized that the source video of the infringement article is quite vague for many times, because this evidence is in favor of the plaintiff to testify that the infringement article released by the defendant is groundless. And this repeated emphasis may occur at the stage which is not suitable to be proposed. In this example, the plaintiff lawyer's overelaboration and argument on some key information should be shown at the later stage of court debate rather than the stage of evidence presentation. In such kind of circumstances, the chief judge as the representative of the court would interrupt the plaintiff's statement on evidence presentation.

In respect to each disputing party, either the plaintiff or the defendant would strive for more interest in this contention; therefore, neither disputing party wants to miss any opportunity to prove the objectivity and acceptability of his party's presented proofs. Both of them want to emphasize the points which are in favor of their interest. This would lead to the repetition of emphasized points and the mention of the legal issues related to the emphasized points.

At this time, the chief judge resorts to interruption to regulate the normal proceeding of the court trial. And the 
chief judge's interruption is usually accompanied by the usage of WA information unit. And the chief judge uses WA1 to interrupt the plaintiff lawyer's overelaboration on some key information of the preceding evidence presentation on infringement behavior.

In this example, on one hand, the chief judge's interruption in WA1 can guarantee the normal proceeding of the court trial; on the other hand, the chief judge's interruption also shows her impartiality to give both parties the relatively fair chance to present their proofs in this interest contention at the stage of defining interest and conflict.

Compared with the more power possessed by the chief judge, the plaintiff lawyer owns relatively less power in the case. However, the plaintiff lawyer has the responsibility to contend for more interests for the plaintiff. Thus, in WA2 unit, the plaintiff lawyer tries his best to sustain a relatively harmonious relationship with the chief judge, which is helpful for the plaintiff lawyer's interest contention for the plaintiff in business dispute settlement.

Furthermore, WA2 unit shows the plaintiff lawyer's agreement with the chief judge's interruption owing to the preceding overelaboration in evidence presentation. Even the plaintiff lawyer wants to occupy more time and speech turns to emphasize the points which are in favor of the plaintiff's interest contention in the preceding evidence presentation, the plaintiff lawyer has to accept the chief judge's interruption and show the obedience to the chief judge owing to the different social identities and different power possession.

It can be found that the social identities of participants involved in disputes can be utilized by both disputing parties' lawyers to contend for interest in the process of business dispute settlement. And the social identities of participants involved in business dispute settlement play a key role in interest contention by means of adopting the positive or negative social identities. Besides, participants' different power possession can influence the way they contend for interest in dispute settlement process as well. The disputing party whose power is comparatively less is inclined to keep a relatively harmonious relationship with the party with more power in interest contention in business dispute settlement.

\subsection{Discourse Analysis of the Effect of Social Relations}

Apart from the influence of social identities on interest contention, social relationship can also affect interest contention in business dispute settlement process.

Since there are many kinds of social relations between groups, and context models cannot possibly accommodate all of them, participants again need to focus on and establish which ones are relevant for adequate discourse production and comprehension. And the actual discursive performance of such relationships is unique in different situations and depends on socially shared and culturally variable knowledge about social relations. In order to reach the necessary reduction of vastly variable information about possible social relations, participants need to generalize and abstract. (van Dijk, 2009).

In the business dispute settlement process, there are many kinds of social relations in interest contention between the disputing parties. And the usage of different social relations in interest contention justifies the data analysis. This section focuses on the illustrations of the use of rapport, complicit relationship, working relationship and friendship.

\subsubsection{The Use of Rapport}

The disputing parties in the court often show their agreement accompanied with head movements and this kind of use of agreement is often repeated in order to maintain a close and harmonious relationship with the chief judge, which is helpful for creating a relatively harmonious atmosphere for the respective lawyer's evidence presentation and evidence challenge to realize their respective interest striving.

In the court, the chief judge is the symbol of fairness and justice and is also the party possessing relatively much more power than other parties involved.

In Example 6, in order to show the impartiality of the chief judge and supply both disputing parties with equal opportunity to strive for their interest, it is necessary for the chief judge to ask both the plaintiff and the defendant whether they are clear about their litigation rights and assumed litigation obligations expressed clearly in the litigation notice and whether the notice needs to be read out in court. It is regarded as a normal part of the whole court proceeding.

Example 6:

01 [审判长]:......<1,1,2,7,WF $>$ 当事人享有的 诉讼权利和应尽的诉讼义务在本院先期送达 的当事人参加诉讼须知中已经予以明示,
$01[\mathrm{~J}]: \ldots<1,1,2,7, \mathrm{WF}>$ The enjoyed litigation rights and assumed litigation obligations of the parties have been expressed clearly in the litigation notice which has been sent to both parties early before the litigation by the 
$<2,7,3,17, \mathrm{WA} 1>$ 双方当事人是否清楚? $<2,7,3,18, \mathrm{WA} 2>$ 是否仍需当庭宣读? 原告?

02[原代二]: $<2,7,3,17, \mathrm{WA} 3>$ 清楚。

03 [原代一]: $<2,7,3,18, \mathrm{WA} 4>$ 不用宣读。

04[审判长]: $<2,7,3,18$, WA5 $>$ 嗯! 被告?

05 [被代一]: $<2,7,3,17, \mathrm{WA} 6>$ (点头) 听清楚

了, $<2,7,3,18, \mathrm{WA} 7>$ 不需要宣读, 不需要宣

读。 court. $<2,7,3,17$, WA1 $>$ Are both of the parties clear about it? $<2,7,3,18$, WA2 $>$ Does the notice still need to be read in court? The plaintiff?

02[PA2]: $<2,7,3,17$, WA3 $>$ Clear.

03[PA1]: $<2,7,3,18$, WA4 $>$ Don't need to read.

$04[\mathrm{~J}]:<2,7,3,18$, WA5 $>$ OK! The defendant?

05[DA1]: $<2,7,3,17$, WA6 $>$ (nodding) Clear. $<2,7,3,18$, WA7 $>$ Do not need to read, do not need to read.

In this example, this rapport is realized by the usage of the plaintiff lawyer's WA3 and WA4 information units and the defendant lawyer's WA6 and WA7 units. As is seen in WA3 and WA4 units, the plaintiff lawyers answer that “清楚” (clear) and “不用宣读” (don’t need to read). WA3 and WA4 information units show the plaintiff lawyer's attitude that they are clear about the enjoyed litigation rights and assumed litigation obligations of the parties. And the plaintiff lawyer also thinks that there is no need to read the litigation rights and obligations of both parties. And WA6 and WA7 units express the defendant lawyer's attitude in the same way. By means of the use of WA information units, both of the plaintiff's and the defendant's lawyers show their agreement and obedience to the chief judge to establish and sustain a harmonious relationship with the court, which is beneficial to both conflicting parties' interest contention.

Spencer-Oatey (2002) finds that relational management is affected by four fundamental rapport management concerns. And the four types of concerns include concern about both face and rights, concerns not only about autonomy but more broadly about cost-benefit, concerns about association as well as autonomy and variable orientations, including interpersonal, intergroup and intragroup.

In Example 6, the plaintiff and the defendants' positive answers to the chief judge which are presented by WA3, WA4 units and WA6, WA7 units respectively not only show their obedience but also elaborate the subtle influence of power distance in the court. More importantly, both of the disputing parties' lawyers want to keep a harmonious relationship with the chief judge, because this rapport management may help them to strive for more interest.

\subsubsection{The Use of Complicit Relationship}

Apart from the use of rapport, other hostile relationships such as complicit relationship can be used for interest contention of both conflicting parties respectively. In order to expand the interest attainment in favor of his own interest, a conflicting party would resort to take advantage of the complicit relationship. The use of this complicit relationship can help him to achieve more interest compensation by testifying the counterparty's complicit relationship with a third party. Conversely, the counterparty will endeavor to deny and prove this complicit relationship with the third party to decrease the possible losses in interest contention in business dispute settlement.

\section{Example 7:}

01[原代一]: ..... $<3,54,4,77, \mathrm{WF} 1>$ 证据 7 是我 们的 $2014 \times \times$ 号公证书, ..... $<3,53,4,80$, WI1 $>$ 那么, 这个证据可以得出一个结论就是被告控 制它所在的页面来进行诋毁原告, 被告与 $\times \times$ 网站是有共谋关系, 共同来侵权的, 那么这个是 我们的证明内容一证据 7 。

02 [审判长]: $<2,17,3,55, \mathrm{WT}>$ 被告, 发表质证意 见。

03[被代二]: $<3,55,4,81, \mathrm{WF} 2>$ 首先, $\ldots . .$. $<3,55,4,82$,WF3 $>$ 其次, $\ldots . .<3,55,4,83$,WI2 $>$ 所以被告与 $\times \times$ 网站不存在任何的共同侵权, 换句话说， $\times \times$ 网站上发布任何的新闻，与页 面上显示被告的推广信息之间没有直接以及 必然的联系, 不存在特殊的利益关系, 不是为 本案涉案新闻特殊设置的一个行为, 不能得出 原告所诉称的被告与 $\times \times$ 网站之间存在共同 侵权。陈述完毕。
01[PA1]: ... $<3,54,4,77$, WF1 $>$ Evidence 7 is our No. $\times \times$ notarial certificate in $2014, \ldots<3,53,4,80$, WI1 $>$ then this evidence can draw a conclusion that it is the defendant that controls the content of $\times \times$ website pages to discredit the plaintiff and the defendant and $\times \times$ website are in the relationship of complicity and commit the infringement together, then this is the content that we have proved of -- evidence 7 .

$02[\mathrm{~J}]:<2,17,3,55, \mathrm{WT}>$ The defendant, issue the views on challenging the preceding evidence.

03[DA2]: $<3,55,4,81$, WF2 $>$ First of all, $\ldots<3,55,4,82$, WF3 $>$ Secondly, ... $<3,55,4,83$, WI2 $>$ so it doesn't exist any contributory infringement between the defendant and $\times \times$ website, in other words, there is no direct and necessary link between any piece of news released on $x \times$ website and the defendant's promotional information on the webpage. And there is no relationship of special interest between the defendant and $\times \times$ website. The news issued on $\times \times$ website involved in this case is not a conduct out of special setting, so it cannot be concluded that contributory infringement exists between the defendant and $x \times$ website. Statement is completed. 
In Example 7, whether the social relationship of cooperation and interest exists between the defendant and $\times x$ website becomes the key point of their interest contention at the stage of defining interest and conflict for the dispute settlement.

WF1 information unit states the evidence 7 to prove that the defendant has controlled the content of web page on $x \times$ website owing to the relationship of cooperation and mutual interest. Because $x \times$ website has released an article which says that the plaintiff has stolen the web users' privacy and monitored their online behaviors, the identification of this cooperative relationship between the defendant and $\times \times$ website will be in favor of the plaintiff for his succeeding fight for interest.

In this example, based on the evidence presented in WF1, the plaintiff lawyer uses WI1 unit to stress that there is the complicit relationship between the defendant and $\times \times$ website by the expression of “被告与 $\times \times$ 网站是有共谋 关系, 共同来侵权的” (the defendant and $\times x$ website are in the relationship of complicity and commit the infringement together). In this way, this complicit relationship is regarded as being proposed based on the previous fact presentation, which can increase the acceptability of this complicit relationship. More importantly, the plaintiff lawyer may expand the plaintiff's interest contention by proposing and proving the existence of this complicit relationship between the defendant and $\times \times$ website.

In such kind of situation, to the defendant, the defendant lawyer has no other choice but to endeavor to decrease the possible losses by testifying that there is no such a complicit relationship between the defendant and $\times x$ website. Thus, WF2 and WF3 present relevant evidence to prove the non-existence of such complicit relationships between the defendant and $\times \times$ website in WI2 with the utterance of “所以被告与 $x \times$ 网站不存在任 何的共同侵权” (so it doesn't exist any contributory infringement between the defendant and $\times \times$ website).

If this social relationship indeed exists between the defendant and $x \times$ website, the denunciation of their contributory infringement will be accepted more easily by the chief judge; therefore, the plaintiff's revealing of social relationship between the defendant and $x \times$ website plays a key role in contending interests for the plaintiff.

Furthermore, this complicit relationship establishment is crucial to the plaintiff's interest contention in that if this complicit relationship between the defendant and $\times \times$ website is proved to be true and is accepted by the court, then there will be another party to bear the plaintiff's interest appeals or compensation together with the defendant. Then the plaintiff can probably attain more interest in interest contention in this dispute settlement.

\subsubsection{The Use of Working Relationship}

Besides, the previous or present working relationship can also be used to make clear the relevant parties' relationship involved in the business dispute. In the present study, the working relationship mainly refers to the relationship between people who interact because of their work (Oxford Living Dictionaries ${ }^{1}$ ). And the working relationship may influence the interest contention in business dispute settlement.

Example 8:

01[审判长]: $<\mathrm{WT} 1>$ 那法庭问你几个问题。

$02[$ 证人]: $<\mathrm{WA} 1>$ 恩。

03 [审判长]: $<\mathrm{WN} 1>$ 你什么时候在现在的这个工作单 位工作?

04[证人]: <WT2 $>$ 现在的这个工作单位吗?

05 [审判长]: $<\mathrm{WA} 2>$ 对。

06[证人]: $<\mathrm{WN} 2>$ 去年 7 月, 2014 年 7 月份。

07[审判长]: <WR $1>$ 之前你在哪个单位工作过?

08[证人]: <WR2 $>$ 之前在被告。

09[审判长]: <WF1 $>$ 之前就是在被告? 在被告公司从 事什么工作？什么部门?

10[证人]: $<\mathrm{WF} 2>$ 市场运营。

11[审判长]: $<\mathrm{WF} 3>$ 市场运营?

12[证人]: <WA3 $>$ 对。
$01[\mathrm{~J}]:<\mathrm{WT} 1>$ Then the court ask you several questions.

$02[\mathrm{~W}]:<\mathrm{WA} 1>$ OK.

$03[\mathrm{~J}]:<\mathrm{WN} 1>$ When do you start to work at this work unit?

$04[\mathrm{~W}]:<\mathrm{WT} 2>$ Do you mean the present work unit?

$05[\mathrm{~J}]:<\mathrm{WA} 2>$ Yes.

06[W]: $<$ WN2>In July of last year, in July 2014.

$07[\mathrm{~J}]:<$ WR $1>$ Where do you work before the present work unit?

$08[\mathrm{~W}]:<\mathrm{WR} 2>\mathrm{I}$ worked at the defendant's company before.

$09[\mathrm{~J}]:<\mathrm{WF} 1>$ Did you work at the defendant's company before?

What kind of work did you take at the defendant's company? Which department did you work in?

$10[\mathrm{~W}]:<\mathrm{WF} 2>$ The department of marketing.

$11[\mathrm{~J}]:<\mathrm{WF} 3>$ The department of marketing?

$12[\mathrm{~W}]:<\mathrm{WA} 3>$ Yes.

\footnotetext{
${ }^{1}$ The website is available at: https://en.oxforddictionaries.com/definition/working_relationship
} 
As is seen, in Example 8, the chief judge asks the witness for the defense for the information about her previous and present working experience. And this interaction occurs at the stage of defining interest and conflict.

Based on the information provided by the witness for the defense in WN2 and WR2, it can be seen that the witness for the defense has worked at the defendant's company before the July of 2014. More specifically, WF2 shows that she has worked in the department of marketing.

In this example, because the interactions between the chief judge and the witness for the defense focus on the witness' previous and present working experience, the information units of WT, WN, WR, and WF have been used. To be specific, WT1 information unit is used to start this round of dialogue by the chief judge and the witness for the defense uses WT2 unit to check the chief judge's preceding question. WA2 is used to show the witness' attitudes and answers to the chief judge's question. The information units of WN2 is used to find out the witness' work time before and now, and WR2 unit finds out the witness' previous and present work places of “之 前在被告” (I worked at the defendant's company before). And the WF2 information unit is used to show the specific work department of “市场运营” (the department of marketing).

Since the witness for the defense has worked in the marketing department of the defendant's company and has been the users of both the plaintiff's and the defendant's products for a long time, she must be clear about the features and operation of both disputing companies' products. Thus, the witness for the defense may supply effective information on the key evidence involved in this case.

However, when the chief judge identifies the witness' previous and present working experience seriously, the witness' social relationship with the defendant reduces the acceptability of her testimony in the court to a certain extent. The disclosure of this social relationship between the witness for the defense and the defendant supplies little help for the defendant's contention for more advantages in defining interest focus later.

\subsubsection{The Use of Friendship}

Apart from the above-mentioned uses of different relationships in interest contention in business dispute settlement, the relationship of friend may affect interest contention in dispute settlement process as well.

Example 9:

01[审判员]: <WT1 > 证人, 你跟今天的双方当事 人之间有什么关系吗?

$01\left[\mathrm{~J}^{\prime}\right]:<\mathrm{WT} 1>$ Witness, do you have any relationship with the two parties?

02[证人]: <WA1>就是原告和被告吗?

$02[\mathrm{~W}]:<\mathrm{WA} 1>$ Do you mean the relationship between the plaintiff and the defendant?

03[审判员]: <WA2>对。原告和被告。 $03\left[\mathrm{~J}^{\prime}\right]:<\mathrm{WA} 2>$ Yes. The relationship between the plaintiff and the defendant.

04[证人]: <WF1 $>$ 原告不认识。然后, 被告认识。 05 [审判员]: $<\mathrm{WT} 2>$ 恩, 什么关系?

$04[\mathrm{~W}]:<\mathrm{WF} 1>\mathrm{I}$ do not know the plaintiff. Then I know the defendant.

06[证人]: $<\mathrm{WF} 2>$ 就是朋友吧。

$05[\mathrm{~J}$ '] $:<\mathrm{WT} 2>$ Well, what's the relationship?

07[审判员]: <WA3>跟被告法定代表人是吗？

$06[\mathrm{~W}]:<\mathrm{WF} 2>$ We are friends.

$07\left[J^{\prime}\right]$ : $<$ WA3 $>$ Do you mean the relationship with the defendant's aggregate?

08[证人]: <WA4>对。

08[W]: <WA4>Yes.

In Example 9, the interactions are concerned with what the relationships of the witness for the defense with the disputing parties of both the plaintiff and the defendant are. And the interactions occur between the judge and the witness for the defense at the stage of defining interest and conflict.

As is shown, WT1 initiates the interaction to ask the witness for the defense what the witness' relationships with the disputing parties are by the judge. Owing to the unfamiliarity with the legal jargon or terms, the witness for the defense inquires the judge whether the disputing parties indicates the plaintiff and the defendant by the use of WA1 unit.

However, the witness for the defense just provides the relatively fuzzy information about her relationship with the plaintiff and the defendant by using WF1 information unit with the utterance of “原告不认识。然后, 被告 认识” (I do not know the plaintiff. Then I know the defendant). In order to attain specific and appropriate information about the witness' relationships with the plaintiff and the defendant, the judge reinitiates the question by another WT2 unit. Under the judge's reinitiating of the same question, the witness for the defense uses WF2 unit to state the fact that she is a friend of the defendant relatively unwillingly in the way of “就是朋友吧” (we are friends). 
At last, WA3 and WA4 units confirm the friendship of the witness for the defense with the defendant by the judge, which can guarantee the accuracy of the witness testimony.

In sum, both the disputing parties try their best to present evidence and justify their views before the interest and conflict is defined. In this example, the witness' relationship with the plaintiff and the defendant may affect the objectivity and acceptability of the witness' testimony. And this plays a key role when the conflicting foci are identified and effects the interests of both disputing parties later.

\section{Conclusion}

The present study has analyzed the social factors that influence interest contention in business dispute settlement. From the data analysis, it can be seen that any conflicting party's lawyer could take advantage of both different social identities and social relationships to attack the counterparty's loopholes or shortcomings and gain more interests for his own party in interest contention. Specifically, in respect to the effect of social identities, the disputing litigants have used positive social identity, negative social identity, and the social identity with power to contend for their respective interest in the dispute settlement. With regard to the effect of social relations, different social relations, including the use of rapport, complicit relationship, working relationship and friendship, have served for the disputing litigants' interest contention in the business dispute settlement.

\section{Acknowledgments}

The research is sponsored by Ph. D Research Programme of Zhongyuan University of Technology [No. 34110495], and the 13th Five-year Key Project Cultivation Programme of School of Foreign Languages of Zhongyuan University of Technology.

The authors' sincere appreciation goes to the anonymous peer-reviewers and editors for their comments on the revision of this article. And our heartfelt gratitude also goes to the assistant editor for her timely mail confirmation and supply of help. I am solely responsible for any remaining errors and shortcomings.

\section{References}

Brown, G., Gillian, B., \& Yule, G. (1983). Discourse analysis. Cambridge University Press. https://doi.org/10.1017/CBO9780511805226

Chen, J. (2011). The reconstruction of prosecution - defence - judge relationship in China: A frame analysis of judges' discourse information processing. International Journal of Speech, Language \& the Law, 18(2). https://doi.org/10.1558/ijsll.v18i2.309

Chen, J. (2017). A corpus-based discourse information analysis of Chinese EFL learners' autonomy in legal case brief writing. English Language Teaching, 10(4), 150-164. https://doi.org/10.5539/elt.v10n4p150

Conley, J. M., \& O’Barr, W. M. (1998). Just words: Law, language, and power. The University of Chicago Press.

Cotterill, J. (2003). Language and power in court: A linguistic analysis of the O. J. Simpson trial. New York: Palgrave Macmillan. Gibbons. https://doi.org/10.1057/9780230006010

$\mathrm{Du}$, J. (2007). A study of the tree information structure of legal discourse. Modern Foreign Languages (Quarterly), 30(1), 40-50.

Du, J. (2009). A study of the discourse information features in advanced writing by English majors. Foreign Language Education, 30(2), 42-46.

$\mathrm{Du}, \mathrm{J}$. (2015). On legal discourse information. Beijing: People's Publishing House.

Du, J. (Ed.). (2013). Discourse analysis. Wuhan: Wuhan University Press.

Fairclough, N. (1995). Critical discourse analysis: The critical study of language. NY: Longman Publishing.

Fan, Y. (2007). Theory and practice of dispute resolution. Beijing: Tsinghua University Press.

Ge, Y. (2014). Resolution of conflict of interest in Chinese civil court hearings: A perspective of discourse information theory. International Journal of Speech Language and the Law, 21(1), 163-168. https://doi.org/10.1558/ijsll.v21i1.163

Gibbons, J. (2003). Forensic linguistics: An introduction to language in the justice system. Oxford: Blackwell.

Guan, X. (2015). Potential speaker-discriminating power of speaking style: Application of discourse information analysis to forensic speaker recognition. International Journal of Law, Language \& Discourse, 5(1), 38-65.

Guo, T. T. (2017). A study on interest contention in business dispute settlement: A discourse information approach (Unpublished Doctoral Dissertation). Guangdong University of Foreign Studies, China. 
Guo, T. T., \& Zhao, Z. X. (2019). The discourse analysis of e-business instant communication from the perspective of Politeness Principle. International Journal of English Linguistics, 9(2), 174-188. https://doi.org/ 10.5539/ijel.v9n2p174

Halliday, M. A. K. (1978). Language as social semiotic: The social interpretation of language and meaning. London: Edward Arnold.

Huai, Y. M. (2014). A procedure research on the production and construal of communicative intention from a multimodal discourse information processing perspective. Foreign Language and Literature, 30(3), 90-95.

Huang, Y. P. (2012). A discourse analysis of lawyer information manipulation in Chinese criminal trials (Unpublished Doctoral Dissertation). Guangdong University of Foreign Studies, Guangzhou, China.

Pan, X., \& Du, J. (2011). Information flow of process control in courtroom question and response. Journal of Foreign Languages, (2), 56-63.

Spencer-Oatey, H. (2002). Managing rapport in talk: Using rapport sensitive incidents to explore the motivational concerns underlying the management of relations. Journal of Pragmatics, 34(5), 529-545. https://doi.org/10.1016/S0378-2166(01)00039-X

Spencer-Oatey, H., \& Xing, J. (2004). Rapport management problems in Chinese-British business interactions. Multilingual communication, 197-222. https://doi.org/10.1075/hsm.3.13spe

Sun, B. (2016). A study on automatic information seeking in Chinese judicial discourse (Unpublished Doctoral Dissertation). Guangdong University of Foreign Studies, Guangzhou, China.

Sun, B., \& Guo, T. (2017). A corpus-based study on information features of Chinese judicial discourse. Journal of Zhongyuan University of Technology, 28(5), 13-18.

van Dijk, T. A. (2008). Discourse and context: A socio-cognitive approach. Cambridge: Cambridge University Press. https://doi.org/10.1017/CBO9780511481499

van Dijk, T. A. (2009). Society and discourse: How social contexts influence text and talk. Cambridge: Cambridge University Press. https://doi.org/10.1017/CBO9780511575273

Vestergaard, B., Helvard, E., \& Sørensen, A. R. (2011). Conflict resolution: Working with conflicts. Denmark: Danish Centre for Conflict Resolution.

Wodak, R. (1985). The Interaction between Judge and Defendant. In T. A. van Dijk (Ed.), Handbook of Discourse Analysis (Vol. 4: Discourse Analysis in Society, pp. 181-91). London: Academic Press.

$\mathrm{Xu}$, Y. P. (2013). Realization of persuasion in Chinese court conciliation: The discourse information approach. Beijing: Science Press.

Yang, W. H. (2009). A discourse analysis of interpersonal business negotiations. Beijing: Science Press.

Yuan, C. (2018). A battlefield or a lecture hall? A contrastive multimodal discourse analysis of courtroom trials. Social Semiotics, 1-25. https://doi.org/10.1080/10350330.2018.1504653

Yue, S. W. (2016). Effective information exchange during conflict management in business meetings (Unpublished Doctoral Dissertation). Guangdong University of Foreign Studies, Guangzhou, China.

Zhang, S. (2016). Authorship attribution and feature testing for short Chinese emails. International Journal of Speech, Language \& the Law, 23(1). https://doi.org/10.1558/ijsll.v23i1.20300

Zhao J. F. (2011). On the information structure and its linguistic realizations in legal discourse: $A$ Chinese-English contrastive discourse analysis. Beijing: Science Press.

Zhong, C. S. (2009). A discursive-psychological study of Judges' judicial behavior (Unpublished Doctoral Dissertation). Guangdong University of Foreign Studies, Guangzhou, China.

\section{Copyrights}

Copyright for this article is retained by the author(s), with first publication rights granted to the journal.

This is an open-access article distributed under the terms and conditions of the Creative Commons Attribution license (http://creativecommons.org/licenses/by/4.0/). 